\title{
Epidemiologic Aspects of Spinal Cord Trauma Cases among Traffic Accident Victims
}

\begin{abstract}
Tatiana Farias Teódulo Palitot ${ }^{1}$, Alessandro Leite Cavalcanti ${ }^{2}$, Gláucia de Souza Abreu ${ }^{3}$, Liege Helena Freitas Fernandes ${ }^{4}$, Cibele da Cruz Prates ${ }^{5}$, Gabriela Pereira Batista6, Priscilla Maria da Silva Nascimento ${ }^{7}$ Elaine Cristina Batista Tavares ${ }^{8}$ Maria Aparecida de Freitas Silveira ${ }^{9}$ Marcia Maria Almeida da Silva ${ }^{10}$
\end{abstract}

\section{Abstract}

Objective: To describe and analyze characteristics of cases of spinal cord Trauma (SCT) among traffic accident victims admitted to a referral hospital.

Method: Descriptive, analytical, cross-sectional study with quantitative approach, developed in the city of Campina Grande, in the state of Paraíba, Brazil. The population consists of 1,884 medical records of patients admitted to hospital after damage caused by traffic accidents from January to December 2016. Data were analyzed using descriptive and inferential statistics, adopting a significance level of $5 \%$.

Results: Among the victims of traffic accidents, there was a male predominance $(85.4 \%)$. The most affected age group was 21 to 30 years (29\%). Accidents involving motorcyclists were predominant (82.9\%) and 43 victims (2.3\%) suffered spinal injury. Among these ones, there was a prevalence of males (86\%), in the age group between 21 and 30 years $(35.7 \%)$. In30 cases $(69.8 \%)$, the victims hadspinal injuries. The cervical level (55.8\%) was dominant. In addition, $46.7 \%$ of the victims were classified as ASIA and there were 9 cases (30\%) of paraplegia and 1 case (3.3\%) of tetraplegia. A bivariate analysis revealed a significant association between the variable presence of SCT and type of accident $(p<0.001)$, use of cervical collar $(p<0.005)$, injuries in other anatomical regions $(p<0.001)$, surgical treatment $(p<0.001)$ and outcome of the patient's situation $(p<0.005)$.
1 Master's degree in Public Health at Paraíba State University (UEPB). Parnamirim, RN, Brazil.

2 Post-doctorate in Pediatric Dentistry at Minas Gerais Federal University (UFMG). Campina Grande, PB, Brazil.

3 Master's degree in Public Health at Paraíba State University (UEPB). Cajazeiras, PB, Brazil.

4 Doctoral student in Dentistry at Paraíba State University (UEPB). Campina Grande, PB, Brazil.

5 Student in Dentistry at Paraíba State University (UEPB). Campina Grande, PB, Brazil.

6 Graduate in Nursing atFaculdade Campina Grande/FAC-CG (UNESC), Campina Grande. PB, Brazil.

7 Graduate in Nursing at UNIFACISA, Centro Universitário. Campina Grande, PB, Brazil.

8 Postgraduate in Dermatological Nursingat Estácio de Sá University. São José de Piranhas, PB, Brazil.

9 Postgraduate in Obstetrics Nursing and Neonatology at Santa Maria University (FSM). São Miguel, RN, Brazil.

110 Postgraduate in ICU, Urgency and Emergency at Centro Integrado de Tecnologia e Pesquisa (CINTEP). Paulista, PB, Brazil.

\section{Contact information:}

Maria Aparecida de Freitas Silveira.

Address: Rua Joca Moreno, 687, Sabino Leite. Postal code: 59920-000 São Miguel/RN, Brazil.

झ" aparecidafreitas1984@hotmail.com 
Conclusions: Among the victims of traffic accidents and SCT there was a predominance of males, young individuals and motorcyclists.

\section{Keywords}

Epidemiology; Traffic-Accidents; Public Health; Spinal Injuries; Spinal Cord Trauma.

\section{Introduction}

Spinal cord trauma (SCT) has increased its incidence rate $[1,2]$ and may trigger a situation that has a devastating influence on the individual's life [1, 23]. Spinal cord trauma is often responsible for the emergence of serious psychological problems, which may continue for up to 10 years after its occurrence, causing changes in family daily life and in the relations of the individual in society [4].

This health problem results in several other conditions capable of increasing its severity, such as pressure injuries, pulmonary infections, deep vein thrombosis and others $[5,6,7]$. According to Sabre et al. [8], infections, cardiovascular problems and suicide were the leading causes of death in patients with SCT, reducing the life expectancy of these individuals compared to others.

Traffic accidents are a major cause of SCT, which, according to Verma et al. [9], are responsible for the occurrence of $66.4 \%$ of trauma in general, being the main cause of spinal injury $[1,10,11]$. These types of accidents increase the severity because they trigger associated trauma, more serious injuries and higher mortality [12], besides causing psychological problems such as Posttraumatic Stress Disorder and depression [13, 14]. Thus they are a serious public health problem, being associated with economic consequences, disabilities, significant losses for the victim and all the family, influencing quality of life, and may lead to death [15].

Thus, observing the importance of traffic accidents as an etiological factor of spinal injury in the
Public Health context, the present study aimed to describe and analyze the characteristics of cases of SCT in traffic accident victims admitted to a referral hospital, in a medium-sized city in northeastern Brazil.

\section{Method}

The study was census based, descriptive, analytical and cross-sectional, developed in the city of Campina Grande, Brazil, whose estimated population was 410,332 inhabitants in 2017 . The city has a total of 112 health facilities that serve the Brazilian Unified Health System (SUS, in Portuguese), 231 health facilities in general and 1,353 inpatient beds [16].

The study was conducted at Dom Luiz Gonzaga Fernandes Emergency and Trauma Hospital, which is part of the hospital network of the State of Paraíba, being a reference in trauma care for 203 cities of Paraíbaand also for cities of other states, such as Rio Grande do Norte, Pernambuco and Ceará [17]. Data collection was performed at the Medical Archive and Statistical Service - SAME (Portuguese initials).

The population consisted of 1,884 medical records of victims of traffic accidents hospitalized from January to December 2016. These accidents involved pedestrians, motorcycles, bicycles and automobiles (including trucks and buses) [18].

The inclusion criterion was the minimum period of hospitalization of 24 hours. Were excluded the medical records of the victims who were hospitali- 
zed at the time of collection, because they were not yet in the SAME and those who had a percentage of lack of information greater than $10 \%[19,20]$.

The variables studied were gender, age, days of the week when the care took place, time of care, use of cervical collar at the time of care, type of accident, presence of SCT, skeletal level of the lesion, affected vertebrae, evaluation of the deficiency according to ASIA scale, paraplegia/quadriplegia diagnosis, trauma in other anatomical regions,craniofacial trauma, surgical treatment and outcome of the victim's situation.

The research instrument used was a form composed of objective questions, subdivided into dichotomous variables or multiple choice categories. Data were collected,from May to December 2017, by three researchers, with higher education in nursing and with experience in assisting patients with SCT, properly trained.

Data were entered by double typing into a database of SPSS (Statistical Package for The Social Sciences, IBM SPSS Armonk, New York, USA) version 20 and analyzed using descriptive statistics (absolute and percentage distributions, mean, median and standard deviation) and inferential statistics(Chisquaredtest and Fisher's exact tests), adopting a significance level of $5 \%$.

The Research Ethics Committee of Paraíba State University approved this research, under the Certificate of Presentation for Ethical Appreciation (CAAE Portuguese initials) number 66123217.3.0000.5187.

\section{Results}

Among the victims of traffic accidents registered, it was found that males represented the most common victims (85.4\%), being the ratio between males and females equivalent to 5.8:1. The most affected age group was between 21 and 30 years (29\%), with a mean age of 33.18 years (Median $=30.0$ years; SD $=15.9$ ), with a minimum of less than 1 year and maximum 94 years old (Table 1).
Table 1. Absolute and percentile distribution of traffic accidents in relation to sociodemographic variables regarding the accident and presence of SCT.

\begin{tabular}{|c|c|c|}
\hline \multirow{2}{*}{ Variables } & \multicolumn{2}{|c|}{ Frequency } \\
\hline & $\mathbf{N}$ & $\%$ \\
\hline \multicolumn{3}{|l|}{$\operatorname{Sex}[1,884]$} \\
\hline Male & 1,609 & 85.4 \\
\hline Female & 275 & 14.6 \\
\hline \multicolumn{3}{|l|}{ Age group $[1,875]$} \\
\hline Less than 1 to 10 years old & 56 & 3.0 \\
\hline 11 to 20 years old & 366 & 19.5 \\
\hline 21 to 30 years old & 544 & 29.0 \\
\hline 31 to 40 years old & 380 & 20.3 \\
\hline 41 to 50 years old & 247 & 13.2 \\
\hline 51 to 60 years old & 151 & 8.1 \\
\hline Over 60 years old & 131 & 7.0 \\
\hline \multicolumn{3}{|l|}{ Part of the day $[1,882]$} \\
\hline Morning & 307 & 16.3 \\
\hline Afternoon & 527 & 28.0 \\
\hline Night & 752 & 40.0 \\
\hline Dawn & 296 & 15.7 \\
\hline \multicolumn{3}{|l|}{ Weekend $[1,884]$} \\
\hline Yes & 855 & 45.4 \\
\hline No & 1,029 & 54.6 \\
\hline \multicolumn{3}{|l|}{ Type of accident $[1,884]$} \\
\hline Pedestrian & 133 & 7.1 \\
\hline Cyclist & 68 & 3.6 \\
\hline Car occupant & 121 & 6.4 \\
\hline Motorcyclist & 1,562 & 82.9 \\
\hline \multicolumn{3}{|l|}{ Presence of SCT $[1,884]$} \\
\hline Yes & 43 & 2.3 \\
\hline No & 1,841 & 97.7 \\
\hline \multicolumn{3}{|l|}{ Outcome $[1,779]$} \\
\hline Discharge from the hospital & 1,527 & 85.8 \\
\hline Transfer & 104 & 5.8 \\
\hline Death & 148 & 8.3 \\
\hline
\end{tabular}


Regarding the accident aspects, it was observed that the majority of the doctor'svisits occurred at night $(55.7 \%)$ and $45.4 \%$ were registered at the weekend. Regarding the type of accident, the most prevalent were those involving motorcyclists (82.9\%), and the occurrence of SCT was $2.3 \%$. In addition, it was found that $8.3 \%$ of the victims died (Table 1).

Table 2 shows that among the victims with SCT, there was a predominance of casesrelated to the cervical region $(55.8 \%)$, with a predominance of vertebrae C6 and C2, with a percentage of 31.4\% and $22.9 \%$, respectively. Among the thoracic vertebrae, Th7 and Th8 represented $19.2 \%$ of the cases and, in the lumbar region, the L1, L2, L4 and L5 vertebrae were equally affected (22.2\%). Among the 43 victims with SCT, 18 (41.9\%) had multiple vertebrae affected.

Table 2 also shows that $69.8 \%$ of the victims had spinal injury, with an incidence of 77.9 per 1,000,000 inhabitants. When classifying them according to the ASIA scale criteria, $46.7 \%$ were considered as ASIA E, followed by ASIA A (36.7\%). In addition, 81.8\% of patients in cases classified as ASIA A were diagnosed with paraplegia.

SCT cases were more prevalent among males (86\%) (male to female ratio was 6:1), aged 21 to 30 years (35.7\%). The average age was 37.0 years (Median = 33.0; SD = 15.3), with a minimum age of 16 and a maximum of 74 years. In $53.5 \%$ of cases, the medical care occurred at night, $60.5 \%$ during the week and $67.4 \%$ involved motorcycle

Table 2. Distribution of SCT cases in relation to its clinical features.

\begin{tabular}{l|c|c|}
\multicolumn{1}{c|}{ Variables } & \multicolumn{2}{c|}{ Frequency } \\
\cline { 2 - 3 } \multicolumn{1}{c|}{} & N & $\%$ \\
\hline Skeletal level [43] & & \\
\hline Cervical & 24 & 55.8 \\
\hline Thoracic & 12 & 27.9 \\
\hline Lumbar & 6 & 14 \\
\hline Uninformed & 1 & 2.3 \\
\hline
\end{tabular}

\begin{tabular}{|c|c|c|c|}
\hline \multirow{2}{*}{\multicolumn{2}{|c|}{ Variables }} & \multicolumn{2}{|c|}{ Frequency } \\
\hline & & $\mathbf{N}$ & $\%$ \\
\hline \multicolumn{4}{|c|}{ Affected vertebrae } \\
\hline \multirow{7}{*}{ Cervical [35] ${ }^{\mathrm{a}}$} & C1 & 1 & 2.8 \\
\hline & $C 2$ & 8 & 22.9 \\
\hline & $\mathrm{C} 3$ & 3 & 8.6 \\
\hline & $\mathrm{C} 4$ & 2 & 5.7 \\
\hline & C5 & 7 & 20 \\
\hline & C6 & 11 & 31.4 \\
\hline & $C 7$ & 3 & 8.6 \\
\hline \multirow{11}{*}{ Thoracic [28] ${ }^{\mathrm{a}}$} & Th3 & 2 & 7.1 \\
\hline & Th4 & 2 & 7.1 \\
\hline & Th5 & 1 & 3.6 \\
\hline & Th6 & 2 & 7.1 \\
\hline & Th7 & 5 & 17.9 \\
\hline & Th8 & 5 & 17.9 \\
\hline & Th9 & 4 & 14.3 \\
\hline & Th10 & 2 & 7.1 \\
\hline & Th11 & 2 & 7.1 \\
\hline & Th12 & 2 & 7.1 \\
\hline & No answer & 1 & 3.6 \\
\hline \multirow{5}{*}{ Lumbar [9] ${ }^{a}$} & L1 & 2 & 22.2 \\
\hline & L2 & 2 & 22.2 \\
\hline & L3 & 1 & 11.1 \\
\hline & L4 & 2 & 22.2 \\
\hline & L5 & 2 & 22.2 \\
\hline \multirow{3}{*}{ Spinal injury [43] } & Yes & 30 & 69.8 \\
\hline & No & 8 & 18.6 \\
\hline & No answer & 5 & 11.6 \\
\hline \multirow{6}{*}{$\begin{array}{l}\text { Classification } \\
\text { according } \\
\text { to ASIA scale } \\
\text { [30] }\end{array}$} & A & 11 & 36.7 \\
\hline & B & 1 & 3.3 \\
\hline & C & 1 & 3.3 \\
\hline & $\mathrm{D}$ & 2 & 6.7 \\
\hline & $E$ & 14 & 46.7 \\
\hline & No answer & 1 & 3.3 \\
\hline \multicolumn{4}{|c|}{ Paraplegia and Tetraplegia Diagnosis [11] } \\
\hline \multicolumn{2}{|c|}{ Paraplegia diagnosed ${ }^{\mathrm{b}}$} & 9 & 81.8 \\
\hline \multicolumn{2}{|c|}{ Tetraplegia diagnosed ${ }^{c}$} & 1 & 9.1 \\
\hline \multicolumn{2}{|l|}{ No answer } & 1 & 9.1 \\
\hline
\end{tabular}


accidents (Table 3). The use of cervical collar was verified in $96.7 \%$ of the victims and $48.8 \%$ had associated trauma. Craniofacial trauma affected $32.6 \%$ of the victims, while death occurred in $17.1 \%$ of the cases. Among the 14 victims who underwent surgical treatment, 8 underwent spinal surgery (Table 3)

Bivariate analysis revealed a significant association between the presence of SCT and the type of accident ( $p<0.001)$, use of cervical collar ( $p$ $<0.05$ ), occurrence of trauma in other body regions ( $p<0.001)$, surgical treatment $(p<0.001)$ and outcome of the victim's situation $(p<0.05)$ (Table 3).

\section{Discussion}

This study aimed to analyze the occurrence of SCT among traffic accident victims hospitalized at a referral hospital of a city in the Northeast of Brazil. It was observed that this type of injury was a serious public health problem, causing disabilities and dependence of individuals [21].

The use of alcohol is one of the main causes of these traffic accidents, because it increases the disrespect of the laws [22], causes changes in the driving ability of drivers [22, 23] and, consequently, makes individuals more exposed to fatal accidents. Accidents reported were more prevalent among males during the third decade of life (Table 1), showing that men are more likely to drive less cautiously [1, 24], since they consume more alcohol and other drugs compared to women.

Regarding the age group, individuals from 21 to 30 years old were predominant, confirming previous studies [25]. This is a worrying fact, since this population group has active participation in labor activities. The accidents, therefore, negatively influence the economy of the country, due to the emergence of incapacities for work and consequent dependence on the public system for survival. This endorse the United Nations stating that the econo-
Table 3. Distribution of SCT cases in relation to sex, age group, part of the day when the medical care occured, weekend, type of accident, use of cervical collar, trauma in other anatomical regions, craniofacial trauma, surgical treatment and outcome of the victim's situation.

\begin{tabular}{|c|c|c|c|c|c|}
\hline \multirow{3}{*}{ Variables } & \multicolumn{4}{|c|}{ SCT } & \multirow{3}{*}{$\%$} \\
\hline & \multicolumn{2}{|c|}{ Yes } & \multicolumn{2}{|c|}{ No } & \\
\hline & $N$ & $\%$ & $\mathrm{~N}$ & $\%$ & \\
\hline \multicolumn{6}{|l|}{ Sex } \\
\hline Male & 37 & 86.0 & 1,572 & 85.4 & \multirow{2}{*}{0.904} \\
\hline Female & 6 & 14.0 & 269 & 14.6 & \\
\hline \multicolumn{6}{|c|}{ Age group (years old) } \\
\hline Less than 1 to 10 & 0 & 0.0 & 56 & 3.0 & \multirow{7}{*}{0.419} \\
\hline 11 to 20 & 4 & 9.5 & 362 & 19.7 & \\
\hline 21 to 30 & 15 & 35.7 & 529 & 28.9 & \\
\hline 31 to 40 & 10 & 23.8 & 370 & 20.2 & \\
\hline 41 to 50 & 4 & 9.5 & 243 & 13.3 & \\
\hline 51 to 60 & 5 & 11.9 & 146 & 8 & \\
\hline Over 60 & 4 & 9.5 & 127 & 6.9 & \\
\hline \multicolumn{6}{|l|}{ Part of the day } \\
\hline Day & 20 & 46.5 & 814 & 44.3 & \multirow{2}{*}{0.769} \\
\hline Night & 23 & 53.5 & 1,025 & 55.7 & \\
\hline \multicolumn{6}{|l|}{ Weekend } \\
\hline Yes & 17 & 39.5 & 838 & 45.5 & \multirow{2}{*}{0.436} \\
\hline No & 26 & 60.5 & 1,003 & 54.5 & \\
\hline \multicolumn{6}{|l|}{ Type of accident } \\
\hline Car occupant & 14 & 32.6 & 107 & 6.5 & \multirow{2}{*}{0.001} \\
\hline Motorcyclist & 29 & 67.4 & 1,533 & 93.5 & \\
\hline \multicolumn{6}{|l|}{ Cervical Collar } \\
\hline Yes & 29 & 96.7 & 509 & 74.5 & \multirow{2}{*}{0.004} \\
\hline No & 1 & 3.3 & 174 & 25.5 & \\
\hline \multicolumn{6}{|c|}{ Trauma in other anatomical regions } \\
\hline Yes & 21 & 48.8 & 1,841 & 100.0 & \multirow{2}{*}{0.001} \\
\hline No & 22 & 51.2 & 0 & 0.0 & \\
\hline \multicolumn{6}{|c|}{ Craniofacial Trauma } \\
\hline Yes & 14 & 32.6 & 770 & 41.8 & \multirow{2}{*}{0.223} \\
\hline No & 29 & 67.4 & 1,071 & 58.2 & \\
\hline \multicolumn{6}{|l|}{ Surgical treatment } \\
\hline Yes & 14 & 32.6 & 1,224 & 66.5 & \multirow{2}{*}{0.001} \\
\hline No & 29 & 67.4 & 617 & 33.5 & \\
\hline \multicolumn{6}{|l|}{ Outcome } \\
\hline Discharge/Transfer & 34 & 82.9 & 1,597 & 91.9 & \multirow{2}{*}{0.038} \\
\hline Death & 7 & 17.1 & 141 & 8.1 & \\
\hline
\end{tabular}


mic losses resulting from these accidents and their consequences may diminish the benefits of economic growth in developing countries [26].

Most accidents happened at night, mainly on weekends. This fact can also be explained by the use of alcohol and other drugs, which is more frequent at night and on weekends [27, 28], as well as more abusive and dangerous attitudes performed by drivers while driving vehicles [28]. In the present study, concerning the time, we had as limitation the fact that the time found in the medical records refers to the service and not to the occurrence of the accident.

Regarding the type of accident, there was a predominance of occurrences involving motorcyclists, corroborating previous studies $[29,30]$. This situation can be explained by inappropriate behavior of motorcyclists, disrespect for traffic laws, lack of exclusive lanes for motorcyclists and the very structure of the motorcycle that makes it difficult for other drivers to see it [28]. It is noteworthy that there is astimulus to manufacture, buy and use motorcycles in Brazil, providing an increase in the number of accidents involving this type of vehicle, as well as compensation for death or disability. Motorcycles have become a widely used means of transportation, mainly due to their versatility and low cost when compared to cars [31]. In Brazilian North and Northeast regions, the number of motorcycles exceeds or is similar to the number of cars [32], making individuals in these regions even more susceptible, since the most used types of vehicles and the safety measures adopted in traffic influence the number of victims involved in these accidents [33].

Among the population of this study, $8.3 \%$ of traffic accident victims died. Other studies have shown lower hospital mortality rates, ranging from 1.0 in various types of trauma [34] to $3.9 \%$ only among victims of traffic accidents [35]. The death rates resulting from traffic accidents decreased in some countries [36, 37], including Brazil [38], however, among victims of external causes, traffic accidents were responsible for the majority of deaths $[25,39]$. Mortality in high-degree accidents may result from the absence of compliance with safety rules and the lack of use of protective equipment [40].

Comparing several countries in relation to the mortality rate, it can be seen that some laws in force in developed countries, aimed at reducing traffic accidents, also helped in developing countries [37]. The educational method directed to changes in the behavior of adolescents, regarding the use of protective equipment and non-ingestion of alcoholic beverages while driving, was efficient [41]. Other contributing factors such as weather circumstances, the technical condition of the vehicle and the driver should also be assessed, as the driver is responsible for a large proportion of accident cases [42].

Thus, to reduce the mortality resulting from these accidents, there is a need for laws aimed at the prevention of traffic accidents, as well as more effective enforcementby the public authorities and educational activities focused on the safe performance of vehicle drivers and the use of protective equipment.

Regarding the SCT, the cervical region has also been described in other studies [7, 9, 11, 43] as the most damaged skeletal level, includingafter motorcycle accidents [44]. Concerning accidents involving automobiles, injury in the lumbar region was predominant [12]. The thoracic region is the most affected when related to road accidents in general [45]. Traumatic spinal cord injury occurs mainly due to situations of hyperflexion, hyperextension, vertical compression, excessive rotation, excessive lateral tilt and sudden excessive traction of the spine $[46,47]$. In order to reduce such movements, the National Traffic Council has made it compulsory for vehicles to wear a three-point seat belt and head restraint in all seat positions. Head restraint is directly related to cervical movement [48]. The fact that motorcycles are the most involved vehicles in accidents and do not have mandatory mechanisms 
to prevent these injuries seems to explain why the cervical level was the most affected in this study.

Regarding the predominance of the most affected vertebra, other studies show different results, being $L 1$ the more frequent $[6,44]$ and most lesions were between Th1 and S5 [49], which shows the importance of knowledge about these characteristics in a given population, generating subsidies for decision-making regarding specific prevention actions, such as the use of cervical collars in initial care by health professionals, and guidance on the importance of the use of head restraints and seat belts in automobiles. These actions may decrease the risk of a cervical injury.

More than two thirds of the victims in the population of this study had spinal injury, a result similar to that described in Cambodia [44] and higher than reported in China [6] and Iran [12]. The incidence of this injury, as found in this study, can be considered high when compared to others [2, 11, 49], which makes this situation even more worrying in this locality.

As traumatic spinal injury may be due to several mechanisms [46, 47], a more detailed study on the mechanism involved in the accident is necessary to make possible comparisons, which was not possible in this study due to the lack of information in the medical records.

Regarding the classification according to the ASIA Scale, our study differs from others ones who also made this assessment, which verified the predominance of ASIA A [10, 44, 45] and ASIA D [49]. Paraplegia was predominant over quadriplegia, and such conditions were only evident in victims who were classified as ASIA A. Other studies classified cases as complete and/or incomplete paraplegia and/or paraplegia [1, 49] and paraplegia/paraparesis or quadriplegia/quadriparesis [10] in all cases. As a result of a complete spinal cord injury, depending on the level of the injury, paraplegia and quadriplegia may occur [50]. DeVivo et al. [51] provide an alternative diagnosis of classifications, subdividing them into 4 groups: (1) C1-C8 ASIA A (complete quadriplegia); (2) C1-C8 ASIA B, C or D (incomplete quadriplegia); (3) Th1-S5 ASIA A (complete paraplegia); and (4) Th1-S5 ASIA B, C or D (incomplete paraplegia). The fact that different forms of diagnosis were used regarding paraplegia/quadriplegia in this study and in the others mentioned, makes it difficult to make further comparison.

However, it is important to highlight the occurrence of paraplegia and quadriplegia in this population, affecting $33.3 \%$ of all cases of this injury, as such situations generally incur disabling conditions which can trigger physical, psychological and economic problems for the victim and his family $[3,4]$.

Men were the predominant victims of SCT, corroborating several studies $[6,7,11,43,45]$. The average age in this study is in agreement with other ones previously performed [7, 10, 12, 44, 45]. Being male, young, using alcohol and illicit drugs are the main risk factors associated with this type of injury [50].

Cases of SCT resulting from accidents involving motorcycles were more frequent, corroborating previous findings $[19,52]$. Accidents involving motorcycles cause a larger number of injuries and more serious ones, which are more frequent in the head, chest, abdomen and extremities, when compared to car accidents [52, 53].

Motorcyclists generally expose themselves to injuries to a greater extent due to misuse or reduced use of protective equipment $[22,54]$. Comparing victims of motorcycle accidents who wore a helmet or not, for example, there were more serious injuries to the head / neck, face, chest and extremities and the occurrence of deaths was significantly higher among motorcycle riders who did not wear a helmet. Regarding the cases of cervical vertebra fractures, this number was also significantly higher concerning those who did not wear a helmet [55].

Regarding the use of cervical collar in the group of victims of SCT, despite the high lack of information in medical records, it was high, showing that health professionals who provide immediate care 
at the scene of accidents adopt the use of collar as a norm, in accordance with the PHTLS (Prehospital Trauma Life Support), which considers its priority use in prehospital trauma care [47].

The occurrence of trauma associated with SCT was also verified in other studied populations [6, $12,43,44]$. The most commonly affected regions are the thoracic one and the head $[6,43]$. In this research, craniofacial trauma affected one third of the victims of SCT. In the United Kingdom, it was found that the occurrence of spinal injury was significant among victims of maxillofacial trauma [56]. In addition, with regard to the etiology of the injury, the occurrence of spinal injuries in victims of oral and maxillofacial trauma resulting from traffic accidents was four times higher. This fact can be explained by the force that is transmitted from the skull and facial skeleton to the cervical spine during the accident, which highlights the need for immobilization and imaging of the cervical spine in all victims of oral and maxillofacial trauma, always considering them as potential victims of spinal injury [56].

An important fact is that, although certain vertebrae were more affected, almost half of the victims of SCT had more than one affected vertebra, a fact evidenced in other studies [6, 12, 44]. In addition, more than half of the victims of SCT who underwent surgical procedures went through spinal surgery, similar to those previously described [44, 57]. In a study conducted in Spain, the reduction in the number of surgical procedures was directly proportional to the number of affected vertebrae [57].

Thus, the fact that this study found a high number of victims with more than one affected vertebra may explain the high rate of surgical procedures performed and, consequently, associated hospital expenses. In addition, in other study [58], despite the completion of surgeries, most patients continued to have clinical symptoms, being unable to return to work, requiring postoperative consultation and health care, indicating the need for direct and indirect costs.
Regarding traffic accidents in general, a study shows that the average stay during hospitalization was almost one week, leading to significant expenses among these victims [52]. In this context, we highlight the importance of this injury resulting from traffic accidents, especially involving motorcycles, as a public health problem, economically affecting the situation of the public health system.

The mortality rate of victims of SCT was lower than that found in Tanzania [7] and higher than that found in Spain [57]. The safety measures adopted in the countries may explain differences in the incidence of SCT, as well as in the occurrence of deaths resulting from them. In Spain, for example, the reduction in the mortality rate from these injuries was mainly due to efficient traffic education campaigns, associated with improvements in road conditions and safety equipment, including seat belts that were included in the rear seats of cars, for example [57].

Comparing deaths in the groups with and without SCT, there was a higher percentage of deaths among victims ofSCT. According to some studies, among the victims of traffic accidents, the majority died due to chest injuries [59] and brain trauma, followed by multiple trauma [60].

In a previous study [43], it was found that among victims of traumatic spinal injuries, the main causes of death were secondary complications to injury in the group of patients who were hospitalized for more than one week, and those who died within the first 24 hours presented associated injuries more often than those who survived the first 24 hours. In addition, another study showed that most deaths among these victims had cervical spine injury between C4 and C5 [57].

Spinal injury has many complications, such as pressure ulcers, postural hypotension, autonomic dysreflexia, deep vein thrombosis, urinary tract infections, neurogenic bowel, and others [61]. Thus, the most frequent deaths among the victims of SCT in the population of this study may be related to the 
higher number of injuries to the cervical spine, the presence of associated injuries and possible complications, but a study correlating such factors would be necessary for further evaluation.

In general, traffic accidents and their consequences can cause economic problems for victims, families and the country, either due to the costs of diagnostic methods, treatments and compensation, or the reduction or loss of productivity of disabling situations that may result from these accidents [62], such as spinal injuries.

For professionals, especially those who participate in the initial care of the victim and those who work in referral hospitals for trauma, this study aimed to provide support on the importance of rigorous assessment of these victims, preventive measures for these injuries and an improvement in patient care, in order to use strategies to resolve possible physical and psychological problems resulting from these injuries, even during initial care and hospitalization.

\section{Conclusion}

Among the victims of traffic accidents with SCT, there was a predominance of male, young individuals and accidents involving motorcyclists, with abuse of alcohol and other drugs.

Given this scenario, it is evident that the findings described in this study can serve as a basis for municipal and state governments to promote educational activities emphasizing the correct use of protective equipment, in an attempt to reduce dangerous attitudes while driving vehicles, as well as to encourage compliance with traffic laws, intensify the correct enforcement of the law and to apply the appropriate penalties to violators, thus reducing the amount of traffic accidents and their consequences.

\section{References}

1. Selassie A, Cao Y, Saunders LL. Epidemiology of traumatic spinal cord injury among person older than 21 years: a populationbased study in South Carolina, 1998-2012. Top Spinal Cord Inj Rehabil. 2015 Nov; 21(4):333-344. doi: 10.1310/sci2104333. PubMed PMID: 26689698; PubMed Central PMCID: PMC4750818.

2. Jain NB, Ayers GD, Peterson EN, Harris MB, Morse L, O'Connor KC et al. Traumatic Spinal Cord Injury in the United States, 1993-2012. JAMA. 2015 Jun; 313(22):2236-2243. doi: 10.1001/ jama.2015.6250. PubMed PMID: 26057284; PubMed Central PMCID: PMC4712685.

3. World Health Organization [Internet]. International perspectives on spinal cord injury. Malta; 2013 [cited 2018 February 18]. Available from: http://apps.who.int/iris/ bitstream/10665/94190/1/9789241564663 eng.pdf?ua=1.

4. Craig A, Tran Y, Guest R, Gopinath B, Jagnoor J, Bryant RA et al. Psychological impact of injuries sustained in motor vehicle accidents: systematic review and meta-nalysis. BMJ Open. 2016 Sep; 6(9):e011993. doi:10.1136 / bmjopen-2016-011993. PubMed PMID: 27609849; PubMed Central PMCID: PMC5020848.

5. Munakomi S, Bhattarai B, Cherian L. Prospective observational research on the clinical profile and outcome analysis among a cohort of patients sustaining traumatic cervical spine and cord injury in a peripheral tertiary spine care centre in Nepal. F1000Res. 2017 Nov; 6:1957. doi:10.12688/f1000research.12911.1. PubMed PMID: 29250317; PubMed Central PMCID: PMC5701450.

6. Wang $H$, Liu $X$, Zhao Y, Ou L, Zhou Y, Li C et al. Incidence and pattern of traumatic spinal fractures and associated spinal cord injury resulting from motor vehicle collisions in China over 11 years. Medicine (Baltimore). 2016 Out; 95(43):e5220. doi:10.1097/MD.0000000000005220. PubMed PMID: 27787384; PubMed Central PMCID: PMC5089113.

7. Moshi H, Sundelin G, Sahlen K-G, Sörlin A. Traumatic spinal cord injury in the north-east Tanzania - describing incidence, etiology and clinical outcomes retrospectively. Glob Health Action. 2017 Aug; 10(1):1355604. doi: 10.1080/16549716.2017.1355604. PubMed PMID: 28856978; PubMed Central PMCID: PMC5645664.

8. Sabre L, Rekand T, Asser T, Kõrv J. Mortality and causes of death after traumatic spinal cord injury in Estonia. J Spinal Cord Med. 2013 Nov; 36(6):687-694. doi:10.1179/204577231 3Y.0000000120. PubMed PMID: 24090049; PubMed Central PMCID: PMC3831332.

9. Verma V, Singh A, Singh GK, Kumar S, Sharma V, Kumar A et al. Epidemiology of trauma victims admitted to a level 2 trauma center of North India. Int J CritIllnInj Sci. 2017 Jun; 7(2):107-112. doi:10.4103/IJCIIS.IJCIIS_27_16. PubMed PMID: 28660164; PubMed Central PMCID: PMC5479072. 
10. Kalfópulos BZ, González AJ, Sánchez AR, Ortiz RR, Aldana EEC, Olivarez LMR. Demographic and clinical characteristics of patients with spinal cord injury: a single hospital-based study. Spinal Cord. 2016 Nov; 54(11):1016-1019. doi:10.1038/ sc.2016.41. PubMed PMID:27067655.

11. Singh A, Tetreault L, Kalsi-Ryan S, Nouri A, Fehlings MG. Global prevalence and incidence of traumatic spinal cord injury. Clin Epidemiol. 2014 Set; 309-331. doi: 10.2147/CLEP. S68889. PubMed PMID: 25278785; PubMed Central PMCID: PMC4179833.

12. Fakharian E, Mohammadzadeh M, Saberi HR, Fazel MR, Rejali M, Akbari $\mathrm{H}$ et al. Spine injury resulting from the car accident: focus on prevention. Asian J Neurosurg. 2017 Abr-Jun; 12(2):180-184. doi: 10.4103/1793-5482.152110. PubMed PMID: 28484526; PubMed Central PMCID: PMC5409362.

13. Lin W, Gong L, Xia M, Dai W. Prevalence of posttraumatic stress disorder among road traffic accident survivors. A PRISMAcompliant meta-analysis. Medicine (Baltimore). 2018 Jan; 97(3):e9693. doi: 10.1097/MD.0000000000009693. PubMed PMID: 29505023; PubMed Central PMCID: PMC5779792.

14. Copanitsanou P, Drakoutos E, Kechagias V. Posttraumatic stress, depressive emotions, and satisfaction with life after a road traffic accident. Orthopaedic Nursing. 2018 Jan; 37(1):4353. doi: 10.1097/NOR.0000000000000417. PubMed PMID: 29369134

15. Ramadani N, Zhjeqi V, Berisha M, Hoxha R, Begolli I, Salihu D et al. Public health profile of road traffic accidents in Kosovo 2010-2015. Maced J Med Sci. 2017 Dec; 5(7):1036-1041. doi: 10.3889/oamjms.2017.214. PubMed PMID: 29362641; PubMed Central PMCID: PMC5771275.

16. Instituto Brasileiro de Geografia e Estatística [Internet]. CensoDemográfico 2010 [cited 2016 February 12]. Available from: https://cidades.ibge.gov.br/brasil/pb/campina-grande/ panorama.

17. Governo da Paraíba [Internet]. Hospital de Trauma de Campina Grande realiza 47 mil atendimentos no primeiro semestre; 2016 [cited2018February 12]. Available from: http://paraiba.pb.gov. br/hospital-de-trauma-de-campina-grande-realiza-47-milatendimentos-no-primeiro-semestre/

18. Ministério dos Transportes [Internet]. Departamento Nacional de Estradas de Rodagem. Diretoria de Desenvolvimento Tecnológico. Glossário de termos técnicos rodoviários; 1997 [cited 2018 February 13]. Available from: http://www1.dnit.gov. br/arquivos internet/ipr/ipr new/manuais/DNER-700-GTTR. pdf.

19. Romero $D E$, Cunha $C B$. Avaliação da qualidade das variáveis sócio-econômicas e demográficas dos óbitos de crianças menores de um ano registrados no Sistema de Informações sobre Mortalidade do Brasil (1996/2001). Cad. Saúde Pública. 2006 Mar [cited 2018 March 14]; 22(3). Available from: http:// www.scielosp.org/pdf/csp/v22n3/22.pdf.
20. Romero DE, Cunha CB. Avaliação da qualidade das variáveis epidemiológicas e demográficas do Sistema de Informações sobre Nascidos Vivos, 2002. Cad. Saúde Pública. 2007 Mar [cited 2018 March 14]; 23(3). Available from: http://www.scielo. br/pdf/csp/v23n3/28.pdf

21. World Health Organization-WHO [Internet]. Malta: International perspectives on spinal cord injury; 2013 [cited 2018 Mar 04]. Available from: http://apps.who.int/iris/ bitstream/10665/94190/1/9789241564663 eng.pdf?ua=1.

22. Mascarenhas MDM, Souto RMCV, Malta DC, Silva MMA, Lima CM, Montenegro MMS. Characteristics of motorcyclists involved in road traffic accidents attended at public urgent and emergency services. Ciênc. saúdecoletiva. 2016 Dez; 21(12).

23. Wiedemann K, Naujoks F, Wörle J, Kenntner-Mabiala R, Kaussner $Y$, Neukum A. Effect of different alcohol levels on take-over performance in conditionally automated driving. Accid Anal Prev. 2018 Jun; 115:89-97. doi: 10.1016/j.aap.2018.03.001. PubMed PMID:29550612.

24. Ghaffari-fam S, Sarbazi E, Daemi A, Sarbazi MR, Nikbakht HA, Salarilak S. The Epidemilogical Characteristics of Motorcyclists Associated Injuries in Road Traffics Accidents; A HospitalBased Study. Bull Emerg Trauma. 2016 Oct [cited 2018 Feb 20]; 4(4):223-229. Available from: https://www.ncbi.nlm.nih.gov/ pmc/articles/PMC5118575/

25. Corassa RB, Falci DM, Gontijo CF, Machado GVC, Alves PAB. Evolução da mortalidade por causas externas em Diamantina (MG), 2001 a 2012. Cad. saúde colet. 2017 Out; 25(3).

26. Organização das Nações Unidas [Internet]. Ruas e estradas do Brasil estão entre as mais perigosas do mundo, alerta Banco Mundial; 2015 [cited 2018 March 4]. Available from: https:// nacoesunidas.org/ruas-e-estradas-do-brasil-estao-entre-asmais-perigosas-do-mundo-alerta-banco-mundial/

27. Martin J-L, Gadegbeku B, Wu D, Viallon V, Laumon B. Cannabis, alcohol and fatal road accidents. PLoS One. 2017 Nov; 12(11):e0187320. doi: 10.1371/journal.pone.0187320. PubMed PMID: 29117206; PubMed Central PMCID: PMC5678710.

28. Golias ARC, Caetano R. Accidents between motorcycles: analysis of cases that occurred in the state of Paraná between July 2010 and June 2011. Cienc. Saude Coletiva. 2013 Maio [cited 2018 Feb 20]; 18(5):1235-46. Available from: http://www.scielo.br/scielo. php?script=sci arttext\&pid=S1413-81232013000500008\&lng= en\&nrm=iso\&tlng=en.

29. Bacchieri G, Barros AJD. Acidentes de trânsito no Brasil de 1998 a 2010: muitas mudanças e poucos resultados. Saude Publica. September 2011 [cited in February 20, 2018]; 45(5):949-963. Available from: http://www.scielo.br/scielo.php?script=sci_ arttext\&pid=S0034-89102011000500017\&lng=en\&nrm=iso\&t| $\underline{n g}=\mathrm{pt}$. 
30. Pavanitto DR, Menezes RAM, Nascimento LFC. Accidents involving motorcycles and potential years of life lost. An ecological and exploratory study. São Paulo Med J. 2018 Jan [cited 2018 Mar 10]; 136(1):4-9. Available from: http://www.scielo.br/pdf/spmj/2018nahead/1806-9460spmi-1516-3180-2017-0098070817.pdf.

31. Vasconcelos EA. Risco no trânsito, omissão e calamidade [livro eletrônico]: impactos do incentivo à motocicleta no Brasil. São Paulo: Ed. do Autor; 2013 [cited 2018 march 5]. Available from: http://files-server.antp.org.br/5dotSystem/download/ dcmDocument/2013/08/29/0D2E1C9E-38D9-478A-A24DBB121A3A295A.pdf.

32. Departamento Nacional de Trânsito [online]. Frota de veículos, por tipo e com placa, segundo as Grandes Regiões e Unidades da Federação. Statistical reports - 2013 to 2015 - [cited 2018 March 4]. Available from: http://www.denatran.gov.br/estatistica/237frota-veiculos.

33. World Health Organization [Online]. Geneva: Global status report on road safety 2015; 2015 [cited 2018 Mar 06]. Available from: http://www.who.int/violence injury prevention/road safety status/2015/Summary GSRRS2015 POR.pdf?ua=1.

34. Bolandparvaz S, Yadollahi M, Abbasi HR, Anvar M. Injury patterns among various age and gender groups of trauma patients in southern Iran: A cross-sectional study. Medicine (Baltimore). 2017 Out; 96(41):e7812. doi:10.1097/MD.0000000000007812. PubMed PMID: 29019874; PubMed Central PMCID: PMC5662297.

35. Sherafati F, Homaie-Rad E, Afkar A, Gholampoor-Sigaroodi R, Sirusbakht S. Risk Factors of Road Traffic Accidents Associated Mortality in Northern Iran; A Single Center Experience Utilizing Oaxaca Blinder Decomposition. Bull Emerg Trauma. 2017 Apr [cited 2018 Apr 3]; 5(2):116-121. Available from: https://www. ncbi.nlm.nih.gov/pmc/articles/PMC5406182/

36. Mahdian $M$, Sehat $M$, Fazel MR, Akbari $H$, Rahimi $H$, Mohammadzadeh M. Road traffic deaths in Kashan region, Iran: An eight-year study (2006-2013). Chin J Traumatol. 2018 Fev; 21(1):54-57. doi: 10.1016/j.cjtee.2017.05.004. PubMed PMID: 29426796; PubMed Central PMCID: PMC5835547.

37. Salari M, Kazemnejad A, Zayeri F. Using Growth Mixture Modeling for Clustering Asian and North African Countries on the Road Injury Death Trend (1990-2010). Oman Med J. 2017 Set; 32(5):417-424. doi: 10.5001/omj.2017.78. PubMed PMID: 29026474; PubMed Central PMCID: PMC5632695.

38. Ladeira RM, Malta DC, Morais Neto OL, Montenegro MMS, Soares Filho AM, Vasconcelos $\mathrm{CH}$ et al. Road traffic accidents: Global Burden of Disease study, Brazil and federated units, 1990 and 2015. Rev Bras Epidemiol. 2017 May [cited 2018 Feb 21]; 20(supl 01):157-170. Available from: http://www.scielo.br/scielo. php?script=sci arttext\&pid=S1415-790X2017000500157\&lng= en\&nrm=iso\&t|ng=en
39. Bazeli J, Aryankhesal A, Khorasani-Zavareh D. Epidemiology of special incidents: Results from national mortality and morbidity registry and the associated factors in Iran in 2014. Electron Physician. 2017 Aug; 9(8):5113-5121. doi: 10.19082/5113. PubMed PMID: 28979750; PubMed Central PMCID: PMC5614300.

40. Ekeke ON, Okonta KE. Trauma: a major cause of death among surgical inpatients of a Nigerian tertiary hospital. Pan Afr Med J. 2017 Sep; 28:6. doi: 10.11604/pamj.2017.28.6.10690. PubMed PMID: 29138652; PubMed Central PMCID: PMC5681011.

41. Charry JD, Ochoa JD, Tejada JH, Navarro-Parra SL, Esquivel N, Vasques $Y$. Education in trauma: An educational alternative that promotes injury prevention. Chin J Traumatol. 2017 Oct; 20(5):275-277. doi: 10.1016/j.cjtee.2017.04.006. PubMed PMID: 28684038; PubMed Central PMCID: PMC5831044.

42. Ramadani N, Zhjeqi V, Berisha M, Hoxha R, Begolli I, Salihu D et al. Public Health Profile of Road Traffic Accidents in Kosovo 2010-2015. Maced J Med Sci. 2017.

43. Lalwani S, Singh V, Trikha V, Sharma V, Kumar S, Bagla R et al. Mortality profile of patients with traumatic spine injuries at a trauma center in India. Indian J Med Res. 2014 Jul [cited 2018 Mar 16]; 140(1):40-45. Available from: https://www.ncbi.nlm. nih.gov/pmc/articles/PMC4181158/

44. Choi J-H, Park PJ, Din V, Sam N, IV V, Park KB. Epidemiology and Clinical Management of Traumatic Spine Injuries at a Major Government Hospital in Cambodia. Spine J Asian. 2017 Dez; 11(6):908-916. doi: 10.4184/asj.2017.11.6.908. PubMed PMID: 29279746; PubMed Central PMCID: PMC5738312 Dec; 5(7):1036-1041. doi: 10.3889/oamjms.2017.214. PubMed PMID: 29362641; PubMed Central PMCID: PMC5771275.

45. Nulle $A$, Tjurina $U$, Erts $R$, Vetra $A$. A profile of traumatic spinal cord injury and medical complications in Latvia. Spinal Cord Ser Cases. 2017 Dez; 3:17088. doi: 10.1038/s41394-0170002-2. PubMed PMID: 29423294; PubMed Central PMCID: PMC5798906

46. Commichou C, Marrotta JT, Janjua N. LesõesRaquianas. In. Rowland LP. Merritt. Tratado de neurologia. 11. ed. Rio de Janeiro: Guanabara Koogan; 2007. p. 466-473.

47. McswainJr NE et al. Atendimento pré-hospitalar ao traumatizado, PHTLS/NAEMT [Tradução Renata Scavone et. al.] 7. ed. Rio de Janeiro: Elsevier; 2011.

48. Resolução CONTRAN n 518 de 29/01/2015. DOU 06/02/2015 [cited 2018 March 6]. Available from: http://imprensanacional. gov.brl.

49. Chamberlain JD, Deriaz O, Hund-Georgiadis M, Meier S, ScheelSailer A, Schubert $M$ et al. Epidemiology and contemporary risk profile of traumatic spinal cord injury in Switzerland. Injury Epidemiology. 2015 Dez; 2(1):28. doi: 10.1186/s40621-0150061-4. PubMed PMID: 26550554; PubMed Central PMCID: PMC4630259. 
50. Smeltzer SC, Bare BG. Brunner\&Suddarth: Tratado de Enfermagem Médico-Cirúrgica. 12. ed. Rio de Janeiro: Guanabara Koogan; 2011.

51. DeVivo M, Biering-Sørensen F, Charlifue S, Noonan V, Post M, Stripling et al. International data set of spinal cord lesions. Spinal Cord. 2006 Sep [cited 2018 Feb 16]; 44:535-540. Available from: https://www.nature.com/articles/3101958

52. Andrade SSCA, Jorge MHPM. Hospitalization due to road traffic injuries in Brazil, 2013: hospital stay and costs. Epidemiol Serv Saude. 2017 Mar [cited 2018 apr 11]; 26(1):31-38. Available from: http://www.scielo.br/scielo.php?script=sci arttext\&pid=\$223796222017000100031\&lng=en\&nrm=iso\&tlng=en

53. Pincus $D$, Wasserstein $D$, Nathens $A B$, Bai $Y Q$, Redelmeier DA, Wodchis WP. Direct medical costs of motorcycle crashes in Ontario. CMAJ. 2017 Nov [cited 2018 Apr 11]; 189(46):E1410-E1415. Available from: http://www.cmaj.ca/ content/189/46/E1410

54. Seerig LM, Bacchieri G, Nascimento GG, Barros AJ, Demarco FF. Use of motorcycle in Brazil: users profile, prevalence of use and traffic accidents occurrence - a population-based study. Cien Saude Colet. 2016 Dec [cited 2018 Apr 12]; 21(12):3703-3710. Available from: http://www.scielo.br/scielo.php?script=sci arttext\&pid=S1413-81232016001203703\&lng=en\&nrm=iso\&t| ng=en.

55. Kuo SCH, Kuo P-J, Rau C-S, Chen Y-C, Hsieh H-Y, Hsieh C-H. The protective effect of helmet use in motorcycle and bicycle accidents: a propensity score-matched study based on a trauma registry system. BMC Public Health. 2017 Aug; 17:639. doi: 10.1186/s12889-017-4649-1. PubMed PMID: 28784110; PubMed Central PMCID: PMC5545860.

56. Mukherjee S, Abhinav K, Revington PJ. A review of cervical spine injury associated with maxillofacial trauma at a tertiary referral center in the UK. Ann R CollSurg Engl. 2015 Jan; 97(1):66-72. doi: 10.1308/003588414X14055925059633. PubMed PMID: 25519271; PubMed Central PMCID: PMC4473904.

57. Bárbara-Bataller E, Méndez-Suárez JL, Alemán-Sánchez C, Sánchez-Enríquez J, Sosa-Henríquez M. Change in the profile of traumatic spinal cord injury over 15 years in Spain. Scand J Trauma ResuscEmerg Med. 2018 Apr; 26(1):27. doi: 10.1186/ s13049-018-0491-4. PubMed PMID: 29622032; PubMed Central PMCID: PMC5887209.
58. Sarrami P, Ekmejian R, Naylor JM, Descallar J, Chatterji R, Harris IA. Spine surgery outcome in patients who sought compensation after a motor vehicle accident: a retrospective cohort study. BMC Surg. 2016 Nov; 16(1):76. doi: 10.1186/s12893-0160192-8. PubMed PMID: 27871323; PubMed Central PMCID: PMC5116816.

59. Yu W, Chen H, Lv Y, Deng Q, Kang P, Zhang L. Comparison of influencing factors on outcomes of single and multiple road traffic injuries: A regional study in Shanghai, China (2011-2014). PLoS One. 2017 May; 12(5):e0176907. doi:10.1371/journal. pone.0176907. PubMed PMID: 28493893; PubMed Central PMCID: PMC5426634.

60. Tékpa BJD, Diemer HC, IssaMapouka PA, NdomaNgatchokpo V, Gassima B, Nali MN. Mortality during road traffic accidents in Bangui, Central African Republic. Med Sante Trop. 2017 Nov; 27(4):426-430. doi: 10.1684/mst.2017.0745. PubMed PMID:29313512.

61. Ministério da Saúde [Internet]. Brasília: Diretrizes de Atenção à Pessoa com Lesão Medular; 2013 [cited 2018 March 6]. Available from: http://bvsms.saude.gov.br/bvs/publicacoes/ diretrizes atencao pessoa lesao medular.pdf.

62. Pan American Health Organization [Internet]. Acidentes de trânsito (news-sheet); 2016 [cited 2018 March 7]. Available from: $\quad$ http://www.paho.org/bra/index.php?option=com co ntent\&view $=$ article\&id=5147: acidentes- de-transito-folhainformativa\&ltemid $=779$
Publish in International Archives of Medicine

International Archives of Medicine is an open access journal publishing articles encompassing all aspects of medical science and clinical practice. IAM is considered a megajournal with independent sections on all areas of medicine. IAM is a really international journal with authors and board members from all around the world. 